

Marcin Karas

\title{
REFORMA LITURGICZNA PIUSA XII I JANA XXIII
}

Lata 50. i 60. XX wieku są szczególnie interesujące dla historyka idei, a także dla badacza dziejów liturgii katolickiej rytu rzymskiego. W tych czasach zapadały decyzje, które przyczyniły się do późniejszego przeprowadzenia soborowej i posoborowej generalnej reformy liturgicznej. Reforma liturgiczna Pawła VI była najbardziej istotną zmianą w nowożytnych dziejach liturgii Kościoła katolickiego, a więc poznanie jej przyczyn i korzeni należy do zagadnień niezwykle istotnych, ciekawych i godnych uwagi ${ }^{1}$.

Gdy mowa o reformie liturgii w XX stuleciu, to na myśl przychodzi najpierw reforma Wielkiego Tygodnia (1955), zmiany rubryk i kalendarza rzymskiego, a na koniec ogłoszenie Nowego Mszału (1969). Warto jednak omówić także niektóre decyzje i wydarzenia z pierwszej połowy XX wieku, które stanowią historyczną całość z tymi powyższymi reformami. Celem niniejszego artykułu będzie zatem refleksja nad reformą liturgiczną papieży Piusa XII (1939-1958) i Jana XXIII (1958-1963), zwłaszcza w zakresie rubryk Brewiarza (Breviarium Romanum) i Mszału Rzymskiego (Missale Romanum). Na szersze badania, a więc np. dotyczące recepcji tych decyzji w całym Kościele, brak miejsca w krótkim artykule. Decyzje zapadające

1 Cf. M. Banaszak, Historia Kościoła katolickiego, t. 4, Warszawa 1992; M. Karas, $Z$ dziejów Kościoła. Ciagłość i zmiana $w$ Kościele rzymskokatolickim $w$ XIX i XX wieku, Sandomierz 2008; Z. Zieliński, Papiestwo i papieże dwóch ostatnich wieków, Warszawa 1983. 
Marcin Karas

\section{LITURGICAL REFORM OF PIUS XII AND JOHN XXIII}

The 1950s and 1960s are of particular interest to the historian of ideas and also to the researcher of the history of Catholic liturgy of Roman ritual. At that time, decisions which contributed to the later conciliar and post-conciliar general liturgical reform were made. Paul VI's liturgical reform was the most significant change in the modern history of the Catholic Church's liturgy, so knowing its reasons and roots is an extremely important, interesting and noteworthy issue ${ }^{1}$.

When it comes to the reform of the liturgy in the 20th century, the first thing that comes to mind is the reform of the Holy Week (1955), the change of the Roman rubrics and calendar, and finally the announcement of the New Missal (1969). However, it is also worth discussing some decisions and events from the first half of the 20th century, which constitute a kind of historical entirety with these reforms. The aim of this paper will therefore be to reflect on the liturgical reform of Pope Pius XII (1939-1958) and John XXIII (1958-1963), especially as regards the Breviary rubrics (Breviarium Romanum) and the Roman Missal rubrics (Missale Romanum). Yet, in a short study there is no room for more extensive research, e.g. on the

${ }^{1}$ Cf. M. Banaszak, Historia Kościoła katolickiego, t. 4, Warsaw 1992; M. Karas, Z dziejów Kościoła. Ciagłość i zmiana w Kościele rzymskokatolickim w XIX i XX wieku, Sandomierz 2008; Z. Zieliński, Papiestwo i papieże dwóch ostatnich wieków, Warsaw 1983 
w Kurii Rzymskiej miały jednak znaczenie kluczowe dla decyzji partykularnych i właśnie dlatego oficjalne dokumenty i komentarze będą źródłową podstawą naszej analizy².

Aby znaleźć istotne zagadnienia wśród wielu obszernych tematów, należy wybrać kwestie zasadnicze i poddać je analizie. W naszym przypadku będzie to reforma kalendarza, a także zmiana klas różnych świąt i decyzje dotyczące rubryk oraz obrzędów mszalnych i brewiarzowych. Nie będziemy badać Rituale Romanum i innych ksiąg liturgicznych. Rozważania dotyczące decyzji Piusa XII i Jana XXIII będą omawiane w odniesieniu do okresu klasycznego (XIX wiek i wcześniej) oraz w porównaniu do zreformowanej liturgii Pawła VI.

Niniejszy artykuł dzieli się na kilka części. Najpierw omówimy (1) okres klasyczny, poprzedzający reformy z XX wieku. Następnie będziemy poszukiwać (2) zasad i idei dla nadchodzących reform, głoszonych gł. przez przedstawicieli tzw. ruchu liturgicznego. Wstępem do poważniejszych reform były (3) decyzje św. Piusa X, zostaną one zatem przedstawione jako następny wątek. W dalszej kolejności przedstawimy (4) reformy Piusa XII (odpowiednio: reformę rubryk i reformę Wielkiego Tygodnia). Po tych zagadnieniach przejdziemy do (5) pierwszych reform Jana XXIII z 1959 r. i do jego reformy rubryk z 1960 r. Punktem dojścia niniejszego opracowania będzie reforma Pawła VI, poprzedzona przez pewne decyzje papieża podjęte podczas II Soboru Watykańskiego (6). Na koniec zaś przedstawimy wnioski (7).

\section{OKRES KLASYCZNY}

Przez okres klasyczny będziemy rozumieć strukturę liturgii rzymskiej od reformy Soboru Trydenckiego (1545-1563) aż do końca XX wieku. Można nazwać tę epokę również okresem trydenckim albo potrydenckim w życiu Kościoła. Przepisy liturgiczne były wówczas oficjalnie ogłaszane, skrupulatnie przestrzegane i wdrażane pod

\footnotetext{
2 Cf. C. Braga, A. Bugnini, Documenta ad instaurationem liturgicam spectantia. 1903-1963, Rzym 2000.
} 
reception of these decisions in the whole Church. The decisions made in the Roman Curia, however, were crucial for particular decisions and that is why official documents and comments will be the source of the analysis ${ }^{2}$.

In order to find relevant issues among many broad themes, it is necessary to select the essential issues and analyse them. In this case, it will be a reform of the calendar, as well as the change of classes for different holidays and decisions on the rubrics and mass and breviary rituals. Neither Rituale Romanum or other liturgical books are examined here, but considerations on the decisions of Pius XII and John XXIII are discussed in relation to the classical period (19th century and earlier) and in comparison with the reformed liturgy of Paul VI.

This article is divided into several parts. First, the classic period, preceding the reforms of the 20th century, is discussed (1). Then a search will be made for (2) principles and ideas for the upcoming reforms, preached by representatives of the so-called liturgical movement. The introduction to more serious reforms were (3) decisions of St. Pius X, so they are presented as the next thread. Further on, Pius XII's reforms will be presented (4) (the reform of the rubrics and the reform of Holy Week respectively). After these issues we will move on to (5) the first reforms of John XXIII in 1959 and to his reform of the 1960s. The final point of this study will be the reform of Paul VI, preceded by certain decisions of the Pope made during the Second Vatican Council (6). The conclusions (7) close this paper.

\section{CLASSIC PERIOD}

The Classic Period will be understood as the structure of the Roman liturgy from the reform of the Council of Trent (1545-1563) to the end of the 20th century. It can also be called the Trent or Trentine

\footnotetext{
${ }^{2}$ Cf. C. Braga, A. Bugnini, Documenta ad instaurationem liturgicam spectantia. 1903-1963, Rome 2000.
} 
nadzorem Kurii Rzymskiej, biskupów oraz przełożonych zakonnych. Zmiany liturgiczne miały bardzo ograniczony charakter. Obrzędy były zasadniczo niezmienne ${ }^{3}$. Najczęściej w kalendarzu rzymskim były dodawane nowe święta, a Kongregacja ds. Obrzędów (Sacra Rituum Congregatio, SRC) podawała zarządzenia i wyjaśnienia dotyczące różnych, nieraz drobnych szczegółów związanych z interpretacją rubryk ${ }^{4}$. System kalendarza, Brewiarza i Mszału Rzymskiego stanowił wielką, rozbudowaną konstrukcję, dokładnie opracowaną, rozwijaną i scentralizowaną 5 .

Od XVIII stulecia zmienia się poważnie obraz świata zachodniego. Społeczeństwa agrarne wchodzą w epokę rewolucji przemysłowej, która zmienia styl życia codziennego. Władze państwowe coraz mocniej ingerują w życie religijne, idee świeckie ograniczają religijność ludności w różnych jej przejawach ${ }^{6}$. Dobitnym przykładem tych procesów są zmiany w dyscyplinie świąt katolickich. Jako przykład nowożytnego laicyzowania obchodów kultu świętych w roku pod wpływem nowego stylu życia można podać zmiany w strukturze świąt obowiązkowych (a zarazem dni wolnych od pracy). W 1642 r. papież Urban VIII wydał bullę Universa per orbem novit Ecclesia, w której ustalił nowy (zmniejszony) wykaz świąt nakazanych (de praecepto) dla całego Kościoła zachodniego 7 . Oprócz wszystkich niedziel, obowiązkowe były m.in. Boże Narodzenie, Obrzezanie

${ }^{3}$ Cf. A. Nojszewski, Liturgia rzymska, wyd. 2 uzupełnione, Warszawa 1914.

${ }^{4}$ O historii tej kongregacji cf. E. Sztafrowski, Kuria rzymska, Warszawa 1981, 9-15.

5 J. Falise, Liturgiae practicae compendium sive Sacrorum rituum rubricarumque Missalis Breviarii et Ritualis Romani compendiosa elucidatio, ed. 2, Ratyzbona 1876.

${ }^{6}$ Współcześni historycy często traktują okres klasyczny nader krytycznie. Cf. „Kiedy jakiś Kościół dochodzi do tego stopnia sformalizowania, nie może już sobie pozwolić na najmniejszy ruch. Tysiące nitek symbolizujących obrzędową drobiazgowość trzyma go przy ziemi, wiąże z przeszłością, unieruchamia”, G. Minois, Kościót i nauka. Dzieje pewnego niezrozumienia. Od Galileusza do Jana Pawła II, przeł. A. Szymanowski, Warszawa 1996, 276.

7 Cf. Urban VIII, Universa per orbem novit Ecclesia, w: Magnum Bullarium Romanum, ed. L. Cherubini, t. 4, Lyon 1712, 230-231. 
period in the life of the Church. The liturgical regulations were then officially proclaimed, scrupulously observed and implemented under the supervision of the Roman Curia, bishops and religious superiors. Liturgical changes were very limited in nature. The rites were essentially unchanging ${ }^{3}$. New holidays were most often added to the Roman calendar, and the Congregation for Rituals (Sacra Rituum Congregatio, SRC) gave orders and explanations concerning various, sometimes small details related to the interpretation of the rubrics ${ }^{4}$. The system of the calendar, the Breviary and the Roman Missal was a large, extensive structure, carefully designed, developed and centralised ${ }^{5}$.

Since the 18th century, the image of the Western world has been changing seriously. Agrarian societies enter an era of industrial revolution, which is changing the way we live. The state authorities increasingly interfere in religious life, secular ideas restrict the religiousness of the population in its various manifestations ${ }^{6}$. A clear example of these processes is the changes in the discipline of Catholic holidays. As an example of modern secularisation of the celebration of the cult of saints in the year under the influence of a new lifestyle, changes in the structure of holy days of obligation (and at the same time days off from work) can be given. Pope Urban VIII issued a 1624 papal bull Universa per orbem novit Ecclesia in which he established a new (reduced) list of holy days of obligation (de praecepto) for the whole Western Church 7 . In addition to all Sundays, the holy days of obligation are following: Christmas, Circumcision, Revelation, Resurrection with the following two days in the octave, Ascension, Pentecost with the following two days in the octave, Most Holy

${ }^{3}$ Cf. A. Nojszewski, Liturgia rzymska, wyd. 2 uzupełnione, Warsaw 1914.

${ }^{4}$ Cf. E. Sztafrowski, Kuria rzymska, Warsaw 1981, 9-15.

5 J. Falise, Liturgiae practicae compendium sive Sacrorum rituum rubricarumque Missalis Breviarii et Ritualis Romani compendiosa elucidatio, ed. 2, Ratyzbona1876.

${ }^{6}$ Cf. G. Minois, Kościól i nauka. Dzieje pewnego niezrozumienia. Od Galileusza do Jana Pawła II, trans. A. Szymanowski, Warsaw 1996, 276.

${ }^{7}$ Cf. Urban VIII, Universa per orbem novit Ecclesia, w: Magnum Bullarium Romanum, ed. L. Cherubini, t. 4, Lyon 1712, 230-231. 
Pańskie, Objawienie, Zmartwychwstanie wraz z dwoma następującymi dniami w oktawie, Wniebowstąpienie, Zesłanie Ducha Świętego wraz z dwoma następującymi dniami w oktawie, Najświętszej Trójcy, Boże Ciało, Znalezienie Krzyża Świętego, cztery święta maryjne, a także święta różnych aniołów i świętych, w tym wszystkich dwunastu Apostołów z osobna. Łącznie w kalendarzu świąt nakazanych było 38 dni w roku kościelnym. W następnych stuleciach papieże, pod laicką presją różnych państw i władców, ograniczali liczbę świąt obowiązkowych. Obecnie, w nowym Kodeksie Prawa Kanonicznego (1983) jest 10, a w Polsce - sześć świąt nakazanych. W miejsce licznych, wolnych od pracy dni świątecznych w roku, współczesny świat wprowadził do swojego kalendarza wolne soboty - w efekcie suma dni wolnych w roku kalendarzowym jest porównywalna, ale ich wydźwięk jest laicki, a nie katolicki.

Innym wyrazem dużej roli przypisywanej poszczególnym elementom liturgii w życiu Kościoła i przy kształtowaniu cywilizacji chrześcijańskiej, było rozbudowanie systemu rubryk Mszału i Brewiarza w okresie klasycznym ${ }^{8}$. Liturgia trydencka (odnowiony i uporządkowany Mszał Rzymski ogłosił po tym soborze św. Pius V bullą Quo primum tempore w 1570 r.) była niezależnym, bogatym w szczegóły światem. Obrzędy sprawowano w języku łacińskim, w kierunku krzyża ustawionego pośrodku ołtarza (versus Deo). Poszczególne dni w roku kościelnym dzieliły się na rozmaite klasy i stopnie: święta (festa), rytu zdwojonego (ritus duplex, o czterech różnych klasach), rytu półzdwojonego (semiduplex) oraz rytu prostego (simplex), dalej: niedziele (dominicae), uprzywilejowane (privilegiatae, I i II klasy) oraz zwykłe (communes), dni powszednie (ferie), większe i mniejsze, a także oktawy (octavas), uprzywilejowane i nieuprzywilejowane oraz wigilie (vigiliae), objęte postem i wolne od tej dyscypliny. W kalendarzu było 17 oktaw i 17 wigilii (do dziś pozostało od 1 do 3).

Specjalne reguły i tabele określały sposoby wyboru czytań i modlitw (orationes, secretae, communiones, postcommuniones)

${ }^{8}$ Cf. A. Nowowiejski, Ceremoniat parafialny. Przewodnik liturgiczny dla duchowieństwa pasterstwem dusz zajętego, wyd. 7, Płock 1931, stron 574. 
Trinity, Corpus Christi, Finding the Holy Cross, four Marian feasts, as well as feasts of various angels and saints, including all 12 Apostles separately. A total of 38 days in the calendar of feasts were prescribed in the church year. In the following centuries, popes, under secular pressure from various countries and rulers, limited the number of holy days of obligation. Currently, there are 10 holy days of obligation in the new Code of Canon Law (1983), and six holy days of obligation in Poland. In place of numerous public holidays per year, the modern world has introduced free Saturdays into its calendar and as a result, the sum of public holidays in a calendar year is comparable, but their overtones are secular and not Catholic.

Another expression of the great role attributed to particular elements of the liturgy in the life of the Church and in the shaping of Christian civilisation was the expansion of the Missal and Breviary rubric system in the classical period ${ }^{8}$. The Trentine Liturgy (the renovated and ordered Roman Missal proclaimed after the Council of St Pius V with the bull Quo primum tempore in 1570) was an independent world, rich in details. The rites were performed in Latin, towards the cross in the middle of the altar (versus Deo). Individual days of the church year were divided into various classes and grades: feasts (festa), double ritual (ritus duplex, with four different classes), semi-double ritual (semiduplex) and simple ritual (simplex), further: Sundays (dominicae), privileged (privilegiatae, class 1 and 2) and ordinary (communes), weekdays (ferie), bigger and smaller, as well as octaves (octavas), privileged and unprivileged and eves (vigiliae), covered by fasting and free from this discipline. There were 17 octaves and 17 vigiliae in the calendar (1 to 3 are still left until today).

Special rules and tables defined the ways of choosing readings and prayers (orationes, secretae, communiones, postcommuniones) depending upon whether holy days of various classes (occurrentia and concurrentia) coincided. The whole system ensured that holidays, Sundays and weekdays were celebrated in fixed proportions. In this

${ }^{8}$ Cf. A. Nowowiejski, Ceremoniat parafialny. Przewodnik liturgiczny dla duchowieństwa pasterstwem dusz zajętego, ed. 7, Płock 1931, pages 574. 
w zależności od spotkania się w jednym dniu świąt różnej klasy (occurrentia i concurrentia). Cały ten system zapewniał obchodzenie świąt, niedziel i dni powszednich w ustalonych proporcjach. W tej hierarchii istniało łącznie 15 różnych stopni dni liturgicznych. Wiek $\mathrm{XX}$ to czas stopniowego upraszczania tego systemu. Pod koniec okresu klasycznego liczba świąt w roku przekraczała 230. Po reformie Pawła VI pozostało ich około 80 (oraz 95 wspomnień dowolnych).

Przykładowo, w dniu 10 sierpnia przypadało święto nakazane (do 1770 r.) św. Wawrzyńca, o rycie zdwojonym drugiej klasy z oktawą. Święto poprzedzała wigilia (bez postu). W dzień święta Msza była sprawowana według własnego formularza, bez Credo, za wyjątkiem niedzieli bądź kościoła, którego św. Wawrzyniec był patronem. W momencie odmawiania imienia tego świętego w Kanonie (w wigilię, w święto i przez całą oktawę) kapłan pochylał głowę. Podczas nieszporów dodawano jeszcze wspomnienie męczenników św. Tyburcjusza i św. Zuzanny z następnego dnia, 11 sierpnia9.

Święci (męczennicy) byli także licznie wymieniani w Kanonie Mszy (22 przed konsekracją i 15 po konsekracji). We współczesnych Modlitwach Eucharystycznych wymienia się tylko kilku świętych z osobna i pozostałych łącznie. Kanon Rzymski, zwany dziś I Modlitwa Eucharystyczną stanowi jedną z możliwości do wyboru celebransa, obok innych, znacznie krótszych modlitw.

Brewiarz kapłański (odnowiony przez św. Piusa V w 1568 r.) dzielił się na siedem godzin kanonicznych: matutinum z jutrznią (laudesy), prymę, tercję, sekstę, nonę, nieszpory i kompletę. W reformie Pawła VI pryma została zniesiona, a z grupy godzin mniejszych, tj. tercji, seksty i nony pozostała jedna do wyboru (modlitwa w ciagu dnia) ${ }^{10}$.

\section{ZASADY I IDEE RUCHU LITURGICZNEGO}

Ruch liturgiczny w Kościele oznacza działalność różnych specjalistów, organizacji i środowisk na rzecz odnowy, upowszechnienia

9 J. Falise, op. cit., 535.

${ }^{10}$ Cf. Liturgia uświęcenia czasu, red. W. Świerzawski, Kraków 1984. 
hierarchy there were a total of 15 different degrees of liturgical days. The 20th century was a time of gradual simplification of the system. At the end of the Classic Period, the number of holidays per year exceeded 230. After the Paul VI reform, there were about 80 (and 95 free memories) left.

For example, on 10 August, there was a feast ordered (until 1770) by St. Lawrence, with a double second class ritual with an octave. The feast was preceded by an eve (without lent). On the day of the feast, Mass was celebrated according to its own form, without the Creed, except on Sunday or the church of which St. Lawrence was the patron saint. At the moment of reciting the name of this saint in the Canon (on the Eve, on the feast itself and throughout the whole octave) the priest bowed his head. During Vespers, the memory of the martyrs of St. Tiburtius and St. Susanna was added the following day, i.e. August $11^{9}$.

The saints (martyrs) were also mentioned in large numbers in the Canon of Mass (22 before consecration and 15 after consecration). In modern Eucharistic Prayers, only a few saints are mentioned separately and the others together. The Canon of Rome, today known as the First Eucharistic Prayer, is one of the possibilities to choose the celebrant, alongside other, much shorter prayers.

The priestly breviary (renovated by St. Pius V in 1568) was divided into seven canonical hours: matutinum with laudes, prima, terce, sext, nones, vespers and complines. In the Paul VI reform, the prime was abolished, and out of the group of minor hours, i.e. terce, sext and nones, there was one left to choose from (praying during the day) ${ }^{10}$.

\section{PRINCIPLES AND CONCEPTS OF THE LITURGICAL MOVEMENT}

The liturgical movement in the Church means the activities of various specialists, organisations and circles for the renewal,

9 J. Falise, op. cit., 535.

${ }^{10}$ Cf. Liturgia uświęcenia czasu, ed. W. Świerzawski, Kraków 1984. 
i pogłębienia katolickiego kultu religijnego oraz ożywienia świadomego udziału wiernych w czynnościach liturgicznych ${ }^{11}$. Można wyróżnić conajmniej dwie fazy istnienia tego ruchu. Jeszcze w XIX wieku we Francji zasłynął na tym polu o. Prosper Guéranger (1805-1875), opat odnowionego (1832) klasztoru pw. św. Piotra w Solesmes (Kraj Loary, zachodnia Francja) i przełożony francuskich benedyktynów. Po okresie kryzysu życia religijnego, spowodowanego we Francji zniszczeniami w dobie rewolucji, o. Guéranger pracował nad odnowieniem tradycyjnej liturgii rzymskiej i chorału gregoriańskiego. Był autorem wielu artykułów i książek, zwłaszcza monumentalnego Roku liturgicznego (L'Année liturgique, 15 tomów).

W wieku XX ruch liturgiczny objął swym głównym zainteresowaniem okres starożytny dziejów Kościoła ${ }^{12}$. Znaną postacią w tym okresie był belgijski benedyktyn, działający wśród robotników o. Lambert Beauduin (1873-1960), autor książki Modlitwa Kościoła (La piété de l'Église, Principes et faits, 1914) oraz redaktor czasopisma „Irénikon” (od 1926).

Promotorem reformy był także pochodzący z Ołomuńca na Morawach kanonik regularny, o. Pius Parsch (1884-1954) z klasztoru w Klosterneuburgu w Dolnej Austrii. Był doktorem teologii Uniwersytetu Wiedeńskiego (1911). Ogłosił m.in. trzytomowy wykład roku kościelnego pt. Das Jahr des Heiles (1923) oraz wiele innych publikacji, w tym 10 tomów kazań z liturgiki. Ruch liturgiczny rozwijał się również w benedyktyńskim klasztorze Maria Laach (Nadrenia-Palatynat). Wśród znanych reformatorów tej epoki można wymienić takich uczonych, jak duszpasterz młodzieży ks. Romano Guardini (1885-1968) z Werony, benedyktyn Odo Casel (1886-1948) z Koblencji, czy ks. Johannes Pinsk (1891-1957) pochodzący ze Szczecina proboszcz w Berlinie oraz wielu innych.

${ }^{11}$ Cf. A. Krzystek, Przedsoborowe «drogi» do generalnej reformy liturgicznej Soboru Watykańskiego II, „Colloquia Theologica Ottoniana” (2005)1, 7-24.

${ }_{12}$ Cf. np. D. Olewiński, Drogi i bezdroża teologii w XX wieku, w: „Christianitas” (2002)13, 78-81. 
dissemination and deepening of Catholic religious worship and the revival of the faithful' conscious participation in liturgical activities ${ }^{11}$. There are at least two phases in the existence of this movement. As early as the 19th century in France, Father Prosper Guéranger (1805-1875), abbot of the renovated (1832) monastery of St. Peter in Solesmes (Pays de la Loire, western France) and the superior of the French Benedictines became famous in this field. After a period of crisis of religious life, resulting from the destruction in France during the revolutionary era, Fr Guéranger worked to renew the traditional Roman liturgy and Gregorian chant. He was the author of many articles and books, especially the monumental Liturgical Year (L'Année liturgique, 15 volumes).

In the twentieth century, the liturgical movement focused on the ancient period in the history of the Church ${ }^{12}$. A well-known figure at that time was Fr Lambert Beauduin (1873-1960), the Belgian Benedictine, working among workers, the author of the book The True Prayer of the Church (La piété de l'Église, Principes et Faits, 1914) and the editor of the magazine Irénikon (since 1926).

The promoter of the reform was also a regular canon from Olomouc in Moravia, Father Pius Parsch (1884-1954) from the monastery in Klosterneuburg in Lower Austria. He was a doctor of theology at the University of Vienna (1911). He gave a three-volume lecture of the church year, Das Jahr des Heiles (1923) and many other publications, including 10 volumes of sermons from the liturgy. The liturgical movement developed also in the Benedictine monastery Maria Laach (Rhineland-Palatinate). The well-known reformers of the time included such scholars as the youth pastor Fr Romano Guardini (1885-1968) from Verona, Benedictine Odo Casel (1886-1948) from Koblenz or Fr Johannes Pinsk (1891-1957) from Szczecin, parish priest in Berlin and many others.

${ }^{11}$ Cf. A. Krzystek, Przedsoborowe «drogi» do generalnej reformy liturgicznej Soboru Watykańskiego II, „Colloquia Theologica Ottoniana” (2005)1, 7-24.

${ }_{12}$ Cf. f.e. D. Olewiński, Drogi i bezdroża teologii w XX wieku, in: „Christianitas” (2002)13, 78-81. 
Rozwój badań naukowych nad historią i znaczeniem liturgii katolickiej, upowszechnienie oświaty i komunikacji, zmiany w stylu życia i inne czynniki wpłynęły na zmianę podejścia władz kościelnych do liturgii katolickiej. Zaczęły się rozwijać refleksje nad koniecznością lepszego poznania historii (,powrót do źródeł”) i bardziej czynnego, świadomego udziału wiernych w życiu liturgicznym Kościoła. Liturgia nie miała już być domeną rubryk i samego tylko duchowieństwa, ale lepiej wykształceni wierni byli zachęcani do poznawania, przeżywania i angażowania się w kult katolicki. Zaczęto publikować dwujęzyczne mszaliki dla wiernych, umożliwiające uczestnikom celebracji śledzenie na żywo tekstów obrzędów, rozważano różne sposoby aktywizacji liturgicznej wiernych w duchu wspólnotowym i międzynarodowym. Problematyce reform liturgicznych poświęcono wiele książek i czasopism specjalistycznych, publikowanych w różnych krajach zachodnich. Powstawały także różne organizacje gromadzące liturgistów (Instytut Liturgiczny w Trewirze, 1947; Centro di Azione Liturgica - CAL we Włoszech, 1949). Od roku 1951 organizowano międzynarodowe kongresy litugiczne w różnych ośrodkach (Maria Laach, Saint-Odile, Lugano, Louvain, Asyż, Montserrat, Monachium).

Wśród idei reform liturgicznych podkreślano zasady odejścia od unifikacji w duchu rzymskim na rzecz partykularyzmu kościołów lokalnych, ograniczenie praktyk pokutnych (jak: przedpoście przez trzy niedziele przed Wielkim Postem ${ }^{13}$, czy też po trzy suche dni cztery razy w roku), uznanie dla wartości świata współczesnego, dialogu, współpracy i działalności ekumenicznej. Żywoty świętych odczytywane w Brewiarzu poddano wnikliwej weryfikacji historycznej. Stopniowo wzrastała rola żywych języków współczesnych i aktywność świeckich w liturgii (modlitwa wiernych, świeccy

${ }^{13}$ Cf. „Okres Przedpościa, znany już w V w. na Wschodzie, przyjął się na Zachodzie w środowiskach monastycznych. Za papieża Hilarego (461-468) dnie stacyjne - środa i piątek - poprzedzające pierwszą niedzielę Wielkiego Postu, stały się dniami postu obowiązującego. Ułożono dla tych dni specjalne formularze mszalne", J. Wierusz-Kowalski, Liturgika, wyd. 2, Warszawa 1956, 196-197. 
The development of scientific research on the history and meaning of Catholic liturgy, the spread of education and communication, changes in lifestyles and other factors contributed to a change in the attitude of church authorities towards Catholic liturgy. Reflections on the necessity of better knowledge of history ("return to the sources") and more active, conscious participation of the faithful in the liturgical life of the Church began to develop. The liturgy was no longer supposed to be the domain of the sections and the clergy alone, but better educated believers were encouraged to get to know, experience and engage in Catholic cult. Bilingual Missalsals for the faithful were published, allowing the participants of the celebration to follow the texts of the rites live, and various ways of liturgical activation of the faithful in the community and international spirit were considered. Many books and specialist magazines published in various Western countries were devoted to liturgical reforms. Various organisations gathering liturgists were also established (Trier Liturgical Institute, 1947; Centro di Azione Liturgica - CAL in Italy, 1949). Since 1951, international liturgical congresses were held in various centres (Maria Laach, Saint-Odile, Lugano, Louvain, Assisi, Montserrat, Munich).

Among the ideas of liturgical reforms, the principles of moving away from Roman-spiritual unification in favour of the particularism of local churches were stressed, the limitation of penitential practices (such as: preaching three Sundays before Lent ${ }^{13}$, or three dry days four times a year), recognition of the values of the modern world, dialogue, cooperation and ecumenical activity. The lives of saints read in the Breviary were thoroughly reviewed from the historical point of view. The role of live modern languages and the activity of the laity in the liturgy (prayer of the faithful, lay ministers of the sacraments, deacons of steel, lay readers) gradually increased. In the liturgy, its community character gained more emphasis ${ }^{14}$. The theologians' approach to the Church Tradition has also changed: the tradition of

13 Cf. J. Wierusz-Kowalski, Liturgika, ed. 2, Warsaw 1956, 196-197.

14 Cf. B. Pylak, Msza św. ofiarą społeczna, in: B. Pylak, W stużbie Bożej prawdy, Lublin 1986, 141-155. 
szafarze sakramentów, diakoni stali, świeccy lektorzy). W liturgii podkreślano bardziej jej charakter wspólnotowy ${ }^{14}$. Zmieniło się również podejście teologów do Tradycji kościelnej: na pierwszy plan wysuwała się tradycja Kościoła starożytnego (biblijna, apostolska i patrystyczna), w miejsce tradycji późniejszej, scholastycznej, monastycznej i trydenckiej ${ }^{15}$.

\section{POSTANOWIENIA ŚW. PIUSA X}

Jeszcze za pontyfikatu Leona XIII (1878-1903) miały miejsce pewne decyzje dotyczące liturgii: papież nakazał odmawianie po każdej cichej Mszy świętej modlitw przy stopniach ołtarza. Były to odpowiednio: trzykrotne Ave Maria, antyfona Salve Regina, oraz modlitwa do Świętego Michała Archanioła (tzw. egzorcyzm prywatny). Zarządzenie to wyrażało ideę walki ze złem i pokusami w świecie współczesnym.

Papież św. Pius X (1903-1914) poświęcił dużo uwagi odnowie życia liturgicznego w Kościele. Wśród jego decyzji znane są zarządzenia dotyczące odnowy muzyki sakralnej, odrodzenia chorału gregoriańskiego, wczesnej Komunii św. dzieci, czy też formacji religijnej opartej na filozofii tomistycznej. Papież zwalczał modernizm, zagrażający podstawom doktryny chrześcijańskiej (encyklika Pascendi Dominici gregis, 1907). Przygotowywał nowy kodeks prawa kanonicznego, ogłoszony już przez jego następcę w 1917 r. Wychodząc naprzeciw zmieniającym się warunkom życia codziennego społeczeństw w epoce przemysłowej, papież zarządził reformę Brewiarza, znacząco skracając długość poszczególnych godzin kanonicznych (np. w matutinum zmniejszono liczbę psalmów z 12 do 9) i dzieląc długie psalmy na mniejsze fragmenty. Cały psałterz odmawiano w ciągu jednego tygodnia.

${ }_{14}$ Cf. B. Pylak, Msza św. ofiara społeczną, w: B. Pylak, W stużbie Bożej prawdy, Lublin 1986, 141-155.

${ }^{15}$ Cf. J. Ratzinger, Wprowadzenie w chrześcijaństwo, przeł. Z. Włodkowa, wyd. 2, Kraków 1994. 
the ancient Church (biblical, apostolic and patristic) came to the fore, replacing the later, scholastic, monastic and Trentine traditions ${ }^{15}$.

\section{RESOLUTIONS OF ST PIUS X}

It was already during the pontificate of Leo XIII (1878-1903) that some decisions concerning the liturgy were made: the pope ordered to recite prayers at the steps of the altar after every silent Mass. Those were, respectively: the three times Ave Maria, the antiphon Salve Regina, and the prayer to St Michael the Archangel (the so-called private exorcism). This order expressed the idea of fighting evil and temptation in the modern world.

Pope Pius X (1903-1914) devoted much attention to the renewal of liturgical life in the Church. Among his decisions there were also resolutions concerning the renewal of sacred music, the revival of the Gregorian chant, early communion of children, or religious formation based on Thomistic philosophy. The Pope fought against modernism, threatening the foundations of Christian doctrine (Encyclical Pascendi Dominici gregis, 1907). He prepared a new code of canon law, already announced by his successor in 1917. In order to meet the changing conditions of everyday life of societies in the industrial age, the Pope ordered a reform of the Breviary, significantly shortening the length of individual canonical hours (e.g. in the matutinum the number of psalms was reduced from 12 to 9) and dividing long psalms into smaller fragments. The whole psaltery was refused within one week.

The changes in the sections, introduced by St. Pius X, were included in the model edition (editio typica) of the Roman Missal, which was not published until after the end of World War I, by Benedict XV (1914-1922) in $1920^{16}$.

15 Cf. J. Ratzinger, Wprowadzenie w chrześcijaństwo, trans. Z. Włodkowa, ed. 2, Kraków 1994.

${ }^{16}$ Cf. Missale Romanum ex decreto Concilii Tridentini restitutum S. Pii V. Pontificis Maximi jussu editum aliorumque Pontificum cura recognitum a S. Pio X. 
Zmiany w rubrykach, zaprowadzone przez św. Piusa X trafily do wzorcowego wydania (editio typica) Mszału Rzymskiego, który został na nowy wydany dopiero po zakończeniu I wojny światowej, już przez Benedykta XV (1914-1922) w roku $1920^{16}$.

\section{REFORMY PIUSA XII}

W 1925 r. papież Pius XI (1922-1939) ustanowił nowe święto, uroczystość Jezusa Chrystusa Króla, przypadające w ostatnią niedzielę października. Natomiast za pontyfikatu jego następcy, Piusa XII (1939-1958) miały miejsce dwie osobne duże reformy, przeprowadzone w odstępie kilku miesięcy, a więc reforma rubryk i reforma Wielkiego Tygodnia. Reforma rubryk została ogłoszona w marcu 1955, a reforma Wielkiego Tygodnia w listopadzie 1955 (została poprzedzona próbnym wprowadzeniem odnowionych obrzędów Wielkiej Soboty w 1951 r.).

Już w 1945 r. Pius XII wydał Motu proprio In cotidianis precibus, ${ }^{17}$ w którym wprowadził do Brewiarza, jako możliwość fakultatywną, nowy przekład Psalmów z języka hebrajskiego na łaciński, który miał uzupełnić albo zastąpić stosowaną dotąd wersję św. Hieronima (Vulgata).

W 1947 r. papież ogłosił encyklikę Mediator Dei ${ }^{18}$ poświęconą życiu liturgicznemu Kościoła. Przedstawiając różne aspekty kultu, poddał w niej także krytyce niewłaściwe kierunki reform. W $1948 \mathrm{r}$. Pius XII powołał Komisję ds. reformy liturgicznej (tzw. Commissio Piana), pod kierunkiem Klemensa kard. Micary (1879-1965), której sekretarzem został lazarysta, ks. Annibale Bugnini (1912-1982),

${ }^{16}$ Cf. Missale Romanum ex decreto Concilii Tridentini restitutum S. Pii V. Pontificis Maximi jussu editum aliorumque Pontificum cura recognitum a S. Pio X. reformatum et Benedicti XV. auctoritate vulgatum (1920), ed. 28, reimpressio, Bonn 2004.

17 Pius XII, In cotidianis precibus, w: „Acta Apostolicae Sedis”, t. 37 (1945), 65-67.

18 Pius XII, Mediator Dei, w: „Acta Apostolicae Sedis”, t. 39 (1947), 521-600, a także Pius XII, Mediator Dei, Kielce 1947. 


\section{REFORMS OF PIUS XII}

In 1925 Pope Pius XI (1922-1939) established a new feast, the feast of Jesus Christ the King, falling on the last Sunday of October. However, during the pontificate of his successor, Pius XII (1939-1958), two separate major reforms took place, carried out a few months apart, i.e. the reform of the rubrics and the reform of Holy Week. The reform of the rubrics was announced in March 1955 and the reform of Holy Week in November 1955 (it was preceded by a trial introduction of renewed Easter Saturday rites in 1951).

It was in 1945 that Pius XII published Motu proprio In cotidianis precibus 17, in which he introduced a new translation of the Psalms from Hebrew into Latin to the Breviary, as an option, to supplement or replace the version of St. Hieronymus (Vulgata) used so far.

In 1947, the Pope announced the encyclical Mediator Dei18, dedicated to the liturgical life of the Church. By presenting various aspects of the cult, he also criticised the wrong direction of reforms. In 1948 Pius XII established the Commission for Liturgical Reform (the so-called Commissio Piana), under the direction of Clement Cardinal Micara (1879-1965), whose secretary was a lazarist, Fr Annibale Bugnini (1912-1982), titular archbishop since $1972^{19}$. The Commission held 82 meetings between 1948-60.

In the reform of the rubrics (Constitution of the Congregation for Rituals Cum hac nostra aetatae $)^{20}$ the Pope simplified the Roman

reformatum et Benedicti XV. auctoritate vulgatum (1920), ed. 28, reimpressio, Bonn 2004.

17 Pius XII, In cotidianis precibus, in: „Acta Apostolicae Sedis”, t. 37 (1945), 65-67.

${ }_{18}$ Pius XII, Mediator Dei, in: „Acta Apostolicae Sedis”, t. 39 (1947), 521-600, also Pius XII, Mediator Dei, Kielce 1947.

19 Cf. A. Bugnini, La riforma liturgica 1948-1975, Rome 1983; J. Stefański, Abp A. Bugnini (1912-1982), promotor posoborowej odnowy liturgicznej, „Ruch Biblijny i Liturgiczny", 36(1983)4, 329-334.

${ }^{20}$ Sacra Rituum Congregatio, Decretum Cum hac nostra aetatae, in: „Acta Apostolicae Sedis", t. 47 (1955), 218-224. 
arcybiskup tytularny od roku $1972^{19}$. Komisja ta odbyła 82 zebrania w latach 1948-1960.

W reformie rubryk (konstytucja Kongregacji Obrzędów Cum hac nostra aetatae ${ }^{20}$ papież dokonał uproszczenia kalendarza rzymskiego. Reforma polegała ponadto na zniesieniu rytu półzdwojonego (semiduplex) świąt, który zastąpiono rytem prostym (simplex), zaś święta rytu prostego stały się wspomnieniami (commemorationes) bez lectio historica $\mathrm{w}$ Brewiarzu. Na początku każdej z godzin brewiarzowych zniesiono odmawianie Pater noster, Ave Maria i Credo. W brewiarzu na niedziele zniesiono również regularne odmawianie wyznania wiary św. Atanazego (za wyjątkiem święta św. Trójcy).

Reformy w Mszale ${ }^{21}$ polegały na zniesieniu (abolentur) Orationes pro diversitate temporum (dodatkowe dwie orationes, secretae i postcommuniones np. w większości niedziel), ograniczeniu odmawiania hymnu Dies Irae podczas mszy pogrzebowych, ograniczeniu stosowania Credo i własnej ostatniej Ewangelii, która została zastąpiona standartowym początkiem Ewangelii św. Jana (z dwoma wyjątkami).

Papież Pius XII zniósł ponadto 14 oktaw ( 9 z nich wywodziło się z VII i VIII wieku) oraz 10 wigilii różnych świąt. W liturgii Wielkiego Tygodnia ograniczono ponadto rolę subdiakona w liturgii.

Reforma obrzędów Wielkiego Tygodnia rozpoczęła się w 1951 r. Wprowadzono wówczas - tytułem eksperymentu - Wigilię Paschalną sprawowaną wieczorem (Ordo Sabbati Sancti instaurati, 9 lutego 1951) ${ }^{22}$. Zasadnicza reforma (Ordo Hebdomadae Sanctae

19 Cf. A. Bugnini, La riforma liturgica 1948-1975, Rzym 1983; J. Stefański, Abp A. Bugnini (1912-1982), promotor posoborowej odnowy liturgicznej, „Ruch Biblijny i Liturgiczny", 36(1983)4, 329-334.

20 Sacra Rituum Congregatio, Decretum Cum hac nostra aetatae, w: „Acta Apostolicae Sedis", t. 47 (1955), 218-224.

${ }^{21}$ Cf. Mszat Rzymski z dodaniem nabożeństw nieszpornych, Tyniec-Brugia 1956.

${ }^{22}$ Cf. Sacra Rituum Congregatio, Decretum Dominicae Resurrectionis vigiliam, w: „Acta Apostolicae Sedis”, t. 43 (1951), 128-137. 
calendar. The reform also consisted in abolishing the semi-double ritual (semiduplex) of feasts, which was replaced by the simple ritual (simplex), and the feasts of the simple ritual became memories (commemorationes) without lectio historica in Breviary. At the beginning of each breviary hour the recitation of Pater noster, Ave Maria and Credo was abolished. In the Breviary on Sundays, the regular recitation of the confession of St. Athanasius (except for the feast of the Trinity) was also abolished.

The reforms in the Missal ${ }^{21}$ consisted in abolishing (abolentur) Orationes pro diversitate temporum (an additional two orationes, secretae and postcommuniones, e.g. on most Sundays), limiting the recitation of the Dies Irae anthem during funeral services, limiting the use of the Credo and its own last Gospel, which was replaced by the standard beginning of the Gospel of John (with two exceptions).

In addition, Pope Pius XII abolished 14 octaves (9 of which originated in the 7th and 8th centuries) and 10 eves of various holidays. Moreover, the role of the subdiacon in the liturgy of Holy Week was limited.

The reform of the Holy Week rites began in 1951, when - as an experiment - the Paschal Eve celebrated in the evening was introduced (Ordo Sabbati Sancti instaurati, 9 February 1951) ${ }^{22}$. The fundamental reform (Ordo Hebdomadae Sanctae instauratus) ${ }^{23}$ was carried out in 1956, by virtue of the General Decree of the Congregation for Rituals of 16 November 1955 entitled Maxima redemptionis nostrae mysteria24.

In the rites of Palm Sunday (Dominica secunda Passionis seu in palmis), which begins Holy Week, liturgical red (color paramentorum est rubeus) was introduced in place of purple at the procession with

${ }^{21}$ Cf. Mszat Rzymski z dodaniem nabożeństw nieszpornych, Tyniec-Brugia 1956.

22 Cf. Sacra Rituum Congregatio, Decretum Dominicae Resurrectionis vigiliam, in: „Acta Apostolicae Sedis”, t. 43 (1951), 128-137.

23 Cf. Ordo Hebdomadae Sanctae instauratus, Vatican City 1956, pages 144.

24 Sacra Rituum Congregatio, Maxima redemptionis nostrae mysteria, in: „Acta Apostolicae Sedis", t. 47 (1955), 838-847. 
instauratus) ${ }^{23}$ dokonała się w 1956 r., na mocy dekretu ogólnego Kongregacji Obrzędów z dn. 16 listopada 1955 r. pt. Maxima redemptionis nostrae mysteria24.

W obrzędach Niedzieli Palmowej (Dominica secunda Passionis seu in palmis), która rozpoczyna Wielki Tydzień, wprowadzono liturgiczny kolor czerwony (color paramentorum est rubeus) w miejsce fioletowego przy procesji z palmami. Poświęcenie palm miało się odbywać na stole ustawionym przed ołtarzem, a modlitwy podczas tego poświęcenia odmawiano przodem do wiernych (versus populo). Przy poświęceniu palm (benedictione ramorum) zlikwidowano prefację, która mówiła o władzy Chrystusa nad władzami świata doczesnego ${ }^{25}$. Modlitwa na koniec procesji także była odmawiana versus populo.

W czytaniach Pasji, przypadających na Wielki Poniedziałek, Wtorek i Środę, w tekstach Ewangelii św. Mateusza, Łukasza i Marka pominięto początkowe fragmenty o ustanowieniu Eucharystii podczas Ostatniej Wieczerzy.

Obrzędy Wielkiego Piątku (Feria sexta in Parasceve) otrzymały nową nazwę, Mszy z darów uprzednio konsekrowanych oraz uroczystej akcji liturgicznej. Dziewięć modlitw wielkopiątkowych, nie posiadających dotąd tytułów, zostało nazwanych własnymi nazwami. Modlitwa siódma, a więc o nawrócenie heretyków i schizmatyków, została określona w duchu ekumenicznym Modlitwa o jedność Kościoła (Pro unitatae Ecclesiae) ${ }^{26}$.

${ }^{23}$ Cf. Ordo Hebdomadae Sanctae instauratus, Watykan 1956, stron 144.

${ }_{24}$ Sacra Rituum Congregatio, Maxima redemptionis nostrae mysteria, w: „Acta Apostolicae Sedis", t. 47 (1955), 838-847.

${ }^{25} \mathrm{Cf}$., ,quia magnum Unigeniti tui nomen, coram regibus et potestatibus huius saeculi, libera voce confintentur", Wielki i święty Tydzień czyli nabożeństwo Wielkiego Tygodnia w językach tacińskim i polskim wedtug Mszatu i Brewiarza Rzymsko-Katolickiego Kościoła, wyd. 2, Wilno 1862, 63.

${ }^{26} \mathrm{~W}$ polskich wydaniach obrzędów Wielkiego Tygodnia zachowywano jednak tradycyjną terminologię. Cf. S. Wójcik, Wielki Tydzień według porządku wznowionego, Warszawa 1957, 130 („Za heretyków i schizmatyków”); F. Małaczyński, Ceremoniat obrzędów Wielkiego Tygodnia, Warszawa 1958, 123 („Módlmy się o powrót do Kościoła schizmatyków i heretyków”). 
palms. The consecration of the palms was to take place on a table set up in front of the altar, and prayers during the consecration were said in front of the faithful (versus populo). During the consecration of the palms (benedictione ramorum), the preface that spoke of Christ's power over the powers of the temporal world was removed ${ }^{25}$. The prayer at the end of the procession was also recited versus populo.

In the readings of the Passions, which fall on Holy Monday, Tuesday and Wednesday, the initial passages about the institution of the Eucharist during the Last Supper were skipped in the texts of the Gospels of St Matthew, Luke and Mark.

The Good Friday rites (Feria sexta in Parasceve) were given a new name, the Mass of Presanctified Gifts and the solemn liturgical action. Nine Good Friday prayers, which have no titles so far, have been named after them. The seventh prayer, that is, for the conversion of heretics and schismatics, was defined in an ecumenical spirit by the Prayer for Unity of the Church (Pro unitatae Ecclesiae) ${ }^{26}$.

The Pater Noster prayer, so far recited by the celebrant himself, was from now on recited (on Good Friday and Saturday) by the faithful together with the priest. The Easter Saturday rites began after this reform without prayers at the altar steps. The number of prophecies read during Easter Eve was reduced from twelve to four. All those changes and shortenings foreshadow the reform of Paul VI (prepared by the same experts), which took several years to come. The above principles were then extended to the whole church year, to include mass rituals outside Holy Week.

In 1955, the Pope also established the feast of St Joseph the Worker on 1 May ( to replace the former feast of St Philip and Jacob, which was moved to May 11).

25 Cf. ,quia magnum Unigeniti tui nomen, coram regibus et potestatibus huius saeculi, libera voce confintentur", Wielki $i$ święty Tydzień czyli nabożeństwo Wielkiego Tygodnia w językach tacińskim i polskim wedtug Mszału i Brewiarza Rzymsko-Katolickiego Kościoła, ed. 2, Wilno 1862, 63.

26 Cf. S. Wójcik, Wielki Tydzień według porzadku wznowionego, Warsaw 1957, 130; F. Małaczyński, Ceremoniat obrzędów Wielkiego Tygodnia, Warsaw 1958, 123. 
Modlitwa Pater Noster, odmawiana dotychczas przez samego celebransa była odtąd odmawiana (w Wielki Piątek i Sobotę) przez wiernych wraz z kapłanem. Obrzędy Wielkiej Soboty rozpoczynały się po tej reformie bez modlitw u stopni ołtarza. Liczbę proroctw czytanych podczas Wigilii Paschalnej zredukowano z dwunastu do czterech. Wszystkie te zmiany i skrócenia zapowiadają późniejsze o kilkanaście lat reformy Pawła VI (przygotowane przez tych samych ekspertów). Rozszerzono wówczas powyższe zasady na cały rok kościelny, na obrzędy mszalne poza Wielkim Tygodniem.

W 1955 r. papież ustanowił również święto św. Józefa Robotnika na dzień 1 maja (w miejsce dotychczasowego święta św. Filipa i Jakuba, które zostało przeniesione na 11 maja).

Oprócz zmian w rubrykach liturgicznych, za czasów Piusa XII, wskutek stosowania idei dialogu ze współczesnymi wymogami życia społecznego (długotrwałe podróże, praca na zmiany, nowe dni świeckie wolne od pracy), w życiu liturgicznym Kościoła wprowadzono możliwość odprawiania Mszy w godzinach wieczornych. Reforma ta wymagała jednoczesnej zmiany $\mathrm{w}$ dyscyplinie postu eucharystycznego ${ }^{27}$. W okresie trydenckim Msze były odprawiane wyłącznie rano, przedpołudniem i krótko po południu ${ }^{28}$. Pius XII zezwolił na odprawianie Mszy wieczornych.

W związku z pozwoleniem na odprawianie mszy wieczornych przedstawimy krótko zmiany w dyscyplinie postu eucharystycznego w drugiej połowie XX wieku. W epoce klasycznej obowiązywał tzw. post naturalny, a więc od północy, aż do komunii św., przyjmowanej zwykle na porannej Mszy. W 1953 r. papież wydał konstytucję apostolską Christus Dominus, ${ }^{29}$ w której określił, że woda nie stanowi naruszenia postu. W 1957 r. Pius XII określił w motu proprio

27 Cf. M. Zegza, Historia i problemy postu eucharystycznego, „Ruch Biblijny i Liturgiczny", 8(1955)1, 47-57.

28 Przepis ten został ujęty w pierwszym Kodeksie Prawa Kanonicznego: „Missae celebrandae initium ne fiat citius quam una hora ante auroram vel serius quam una hora post meridiem", Codex Iuris Canonici, Watykan 1917, can. 821.

29 Cf. Pius XII, Christus Dominus, w: „Acta Apostolicae Sedis” t. 45 (1953), $15-24$. 
Apart from the amendments to the liturgical sections, during the time of Pius XII, due to implementation of the idea of dialogue with the contemporary requirements of social life (long journeys, work shifts, new secular days off), the possibility of celebrating Mass in the evening was introduced in the Church's liturgical life. Such a reform required a simultaneous change in the discipline of Eucharistic fasting ${ }^{27}$. In the Trentino period, Masses were celebrated only in the morning, before the midday and shortly after ${ }^{28}$. Pius XII allowed for the celebration of Mass in the evening.

Further to the permission to celebrate the evening mass, the paper will briefly present the changes in the discipline of Eucharistic fasting in the second half of the 20th century. In the classical era, there was the so-called natural fasting, i.e. from the midnight until the Holy Communion, usually received at the morning Mass. In 1953 the Pope issued the Apostolic Constitution Christus Dominus29, in which he stated that water is not a violation of the fast. In 1957 Pius XII stated in his motu proprio Sacram communionem 30 that fasting should last for three hours from solid food and for one hour from drinks. At the Second Vatican Council, Paul VI gave his consent (concessio) in 1964 to shorten fasting to one hour ${ }^{31}$. In 1973 an instruction was issued by Immensae caritatis, which allowed patients to shorten their fasts to a quarter of an hour and believers over 60 years of age to reduce their fasts to under one hour ${ }^{32}$. It is worth noting that all these

${ }^{27}$ Cf. M. Zegza, Historia i problemy postu eucharystycznego, ,Ruch Biblijny i Liturgiczny", 8(1955)1, 47-57.

28 „Missae celebrandae initium ne fiat citius quam una hora ante auroram vel serius quam una hora post meridiem”, Codex Iuris Canonici, Vatican City 1917, can. 821.

${ }^{29}$ Cf. Pius XII, Christus Dominus, in: „Acta Apostolicae Sedis” t. 45 (1953), $15-24$.

${ }^{30}$ Cf. Pius XII, Sacram communionem, in: „Acta Apostolicae Sedis” t. 49 (1957), 177-178

31 The Canon Law Digest, t. 6, Milwaukee 1994, 566.

32 Kongregacja Sakramentów, Instrukcja Immensae caritatis, „Wiadomości Diecezjalne" (Katowice), (1974), 72-78. 
Sacram communionem, ${ }^{30}$ że post powinien trwać przez trzy godziny od pokarmu stałego i przez godzinę od napojów. Podczas obrad II Soboru Watykańskiego Paweł VI udzielił w 1964 r. zgody (concessio), aby post skrócić do jednej godziny ${ }^{31}$. W 1973 r. została wydana instrukcja Immensae caritatis, mocą którego chorzy mogą skrócić post do kwadransa, a wierni powyżej 60 roku życia mogą zmniejszyć post poniżej jednej godziny ${ }^{32}$. Warto dodać, że we wszystkich tych dokumentach napisano, aby wierni potraktowali przyznane ulgi jako wyjątek, oraz znalazła się zachęta do samodzielnego uzupełnienia rozluźnionej dyscypliny osobistymi praktykami ascetycznymi ${ }^{33}$.

Znany zwolennik i czołowy animator reformy liturgicznej, abp A. Bugnini określił decyzje reformatorskie Piusa XII mianem mostu, który prowadzi od starego w nowy świat oraz punktu zwrotnego w dziejach rytu rzymskiego. Jego zdaniem, był wtedy tworzony taki świat liturgiczny, w którym współczesny człowiek czuje się dobrze.

\section{DECYZJE JANA XXIII}

Wkrótce po objęciu tronu papieskiego, Jan XXIII (1958-1963) ogłosił swoje pierwsze zarządzenia reformatorskie, zapowiedział też (1959) zwołanie Soboru Powszechnego. Wracając do wcześniejszych,

${ }^{30}$ Cf. Pius XII, Sacram communionem, w: „Acta Apostolicae Sedis” t. 49 (1957), 177-178.

31 The Canon Law Digest, t. 6, Milwaukee 1994, 566.

${ }^{32}$ Kongregacja Sakramentów, Instrukcja Immensae caritatis, „Wiadomości Diecezjalne" (Katowice), (1974), 72-78.

${ }^{33}$ Cf. „Gdy więc przez dyspensy pomniejszać się będą trudności dla ciała, duch wedle możności powinien dopełniać zasługi albo przez głębszą wewnętrzną pokutę, albo innymi sposobami, wedle tradycyjnych praktyk Kościoła. Kościół, gdy pomniejsza posty, zwykle nakazuje wypełnianie innych dobrych uczynków. Wszyscy więc, którzy z ulg tych korzystać będą, niech tym gorliwsze do nieba zanoszą błagania, niech adorują Boga, dzięki Mu czynią, pokutują za grzechy, o nowe niech błagają pomoce i łaski z nieba", Pius XII, Konstytucja Apostolska Christus Dominus, w: „Wiadomości Diecezjalne” (Katowice), 1953, 1-9. 
documents state that the faithful should treat the granted allowances as an exception, and that there is an incentive to supplement the relaxed discipline with personal ascetic practices ${ }^{33}$.

A well-known supporter and leading animator of liturgical reform, Archbishop A. Bugnini described the reform decisions of Pius XII as a bridge that leads from the old to the new world and a turning point in the history of the Roman rite. In his opinion, at that time a liturgical world was being created where contemporary man feels well.

\section{DECISIONS OF JOHN XXIII}

Shortly after taking the papal throne, John XXIII (1958-1963) announced his first reform orders, and also announced (1959) the convening of the General Council. Coming back to earlier but unrealised initiatives, the Pope added the name of St Joseph to the 37 saints who were mentioned in the Canon of Mass ${ }^{34}$.

In 1959, one of the Good Friday prayers was revised by decision of the Pope $^{35}$. When speaking of the conversion of the followers of Judaism, the Pope ordered the removal of the adjective ,unfaithful"(perfidis) indicating their infidelity to the teaching of Jesus Christ (oremus et pro perfidis Judaeis). Further amendments to the prayer were made in the reform of Paul VI ${ }^{36}$.

On July 23, 1960, Pope John XXIII , on his own initiative, issued an apostolic letter Rubricarum instrictum, concerning changes in the Breviary and Roman Missal rubrics ${ }^{37}$. A comprehensive ordinance (general decree) of the Congregation for Rituals with a new code

${ }^{33}$ Cf. Pius XII, Konstytucja Apostolska Christus Dominus, in: „Wiadomości Diecezjalne" (Katowice), 1953, 1-9.

${ }^{34}$ Cf. A. Nowowiejski, Msza Święta, Warsaw 2001, 835.

${ }_{35}$ Cf. Ephemerides Liturgicae, vol. 74 (1960), 133.

${ }^{36}$ Cf. L. Accattoli, Kiedy papież prosi o przebaczenie. Wszystkie «mea culpa» Jana Pawła II, trans. A. Dudzińska-Facca, Kraków 1999, 27-30.

37 Cf. John XXIII, Rubricarum instructum, in: „Acta Apostolicae Sedis”, vol. 52 (1960), 593-595, also „Wiadomości Archidiecezjalne Warszawskie”, vol. 51 (1961), 4-6. 
ale niezrealizowanych inicjatyw, papież dodał imię św. Józefa do 37 świętych, którzy byli wymieniani w Kanonie Mszy ${ }^{34}$.

W 1959 r. decyzją papieża została poddana korekcie jedna z modlitw Wielkiego Piątku ${ }^{35}$. Przy słowach o nawrócenie wyznawców judaizmu, papież polecił usunąć przymiotnik „,wiarołomni” (perfidis) wskazujący na ich niewierność wobec nauczania Jezusa Chrystusa (oremus et pro perfidis Judaeis). Dalsze zmiany w tej modlitwie dokonały się w reformie Pawła $\mathrm{VI}^{36}$.

23 lipca 1960 r. papież Jan XXIII wydał z własnej inicjatywy pismo apostolskie Rubricarum instrictum, dotyczące zmian w rubrykach Brewiarza i Mszału Rzymskiego ${ }^{37}$. Do pisma tego dodano obszerne zarządzenie (dekret ogólny) Kongregacji Obrzędów z nowym kodeksem rubryk ${ }^{38}$. Przepisy te weszły w życie 1 stycznia 1961 r., zaś nowe wydanie Mszału rzymskiego ukazało się w 1962 r.

Brewiarz kapłański został skrócony. Jednocześnie wydano zachętę, aby duchowni samodzielnie nadrabiali w miarę możliwości powstałe ograniczenia ${ }^{39}$. Przy rozdawaniu Komunii św. wiernym we mszy opuszczono odmawianie dodatkowego Confiteor.

${ }^{34}$ Cf. „Do kanonu nie wszyscy święci zostali włączeni od razu, ale kolejno aż do czasów św. Grzegorza Wielkiego, tj. do czasu, w którym liturgia rzymska została ustalona. Odtąd Kościół rzymski, idąc za swoją starożytną tradycją, do swego kanonu już nie wprowadza żadnych świętych imion (...) gdy za Leona XIII (...) podano prośbę podpisaną przez więcej niż 600 kardynałów i biskupów, o dodaniu imienia św. Józefa (...) prośba ta odrzucona została”. A. Nowowiejski, Msza Święta, Warszawa 2001, 835.

${ }^{35}$ Cf. Ephemerides Liturgicae, t. 74 (1960), 133.

${ }^{36}$ Cf. L. Accattoli, Kiedy papież prosi o przebaczenie. Wszystkie «mea culpa» Jana Pawła II, przeł. A. Dudzińska-Facca, Kraków 1999, 27-30.

${ }^{37}$ Cf. Jan XXIII, Rubricarum instructum, w: „Acta Apostolicae Sedis”, t. 52 (1960), 593-595, a także „Wiadomości Archidiecezjalne Warszawskie”, t. 51 (1961), 4-6.

${ }^{38}$ Cf. Sacra Rituum Congregatio, Decretum Novum rubricarum, w: „Acta Apostolicae Sedis", t. 52 (1960), 596-685.

${ }^{39} \mathrm{Cf}$. "Hos autem et omnes qui Officio divino persolvendo tenentur, paterno hortamur animo, ut si quid in eodem divino Officio breviatur, hoc maiore diligentia ac devotione compensetur. Cum porro lectio quoque sanctorum Patrum aliquantisper 
of sections was attached to this letter ${ }^{38}$. The regulations came into force on January 1, 1961, and a new edition of the Roman Missal was published in 1962.

The priestly Breviary was shortened. At the same time, the clergy were encouraged to make up for those limitations as far as possible ${ }^{39}$. When the Holy Communion was given to the faithful, the additional Confiteor was abandoned at Mass.

The nature of the changes in the hierarchy of holy days in the church year allows one to see the ideas underlying the reforms of John XXIII, i.e. the principle of simplicity. At that time, the Congregation eliminated the greater double rite, the simple rite and the privileged days. Sundays were divided into two classes and holidays into four. Eves were divided into three classes, just like holidays. Octaves were divided into two classes. Several holidays were given a reduced rank, becoming memories. On dry Saturdays, numerous (5) readings were abandoned.

Some feasts were removed: the feast of the Holy See in Rome (18 January), of St John in front of the Latin Gate (6 May), of St Michael the Archangel (8 May), of St Leo II (3 July), of St Anaklet (13 July), of St Peter in the Chains (1 August), and of the finding of St Stephen's body (3 August). The aim of the amendment was to simplify the rubrics and eliminate certain types of repetitions existing in the calendar, thus avoiding the occurrence of several different, yet similar feast in honour of the same saint.

\footnotetext{
${ }^{38}$ Cf. Sacra Rituum Congregatio, Decretum Novum rubricarum, w: „Acta Apostolicae Sedis", t. 52 (1960), 596-685.

${ }^{39}$ Cf. „Hos autem et omnes qui Officio divino persolvendo tenentur, paterno hortamur animo, ut si quid in eodem divino Officio breviatur, hoc maiore diligentia ac devotione compensetur. Cum porro lectio quoque sanctorum Patrum aliquantisper quandoque minuatur, omnes enixe clericos hortamur, ut volumina Patrum, tanta sapientia ac pietate referta, assidue prae manibus legenda ac meditanda teneant", John XXIII, Rubricarum instructum, 6 .
} 
Charakter zmian w hierarchii świąt w roku kościelnym pozwala dostrzec idee, leżące u podstaw reform Jana XXIII, a więc gł. zasadę prostoty. Kongregacja zlikwidowała wówczas ryt zdwojony większy, ryt zdwojony, ryt prosty oraz dni uprzywilejowane. Niedziele podzielono na dwie klasy, ferie zaś na cztery. Wigilie dzieliły się na trzy klasy, podobnie jak święta. Oktawy podzielono na dwie klasy. Kilka świąt otrzymało obniżoną rangę, stając się wspomnieniami. W soboty suchych dni opuszczone zostały liczne (5) czytania.

Z istniejących wcześniej świąt zostały zlikwidowane: święto stolicy św. Piotra w Rzymie (18 stycznia), św. Jana przed Bramą Łacińską (6 maja), zjawienie się św. Michała Archanioła (8 maja), św. Leona II (3 lipca), św. Anakleta (13 lipca), św. Piotra w Okowach (1 sierpnia), a także znalezienie ciała św. Szczepana (3 sierpnia). Celem tej zmiany było uproszczenie rubryk i likwidacja pewnego typu powtórzeń istniejących w kalendarzu, a więc uniknięcie występowania kilku różnych, podobnych świąt ku czci tego samego świętego.

Jednocześnie Jan XXIII wystąpił w obronie języka łacińskiego w życiu Kościoła, wydając konstytucję apostolską Veterum sapientia (22 lutego 1962) ${ }^{40}$.

\section{REFORMA PAWLA VI}

Edycja Mszału rzymskiego z 1962 r. była ostatnim wydaniem wzorcowym tzw. mszału trydenckiego, z którego korzysta obecnie szereg różnych katolickich wspólnot tradycjonalistycznych.

Drugi Sobór Watykański (1962-1965) ogłosił, jako pierwszy ze swych dokumentów, Konstytucję o liturgii Sacrosanctum Concilium

quandoque minuatur, omnes enixe clericos hortamur, ut volumina Patrum, tanta sapientia ac pietate referta, assidue prae manibus legenda ac meditanda teneant", Jan XXIII, Rubricarum instructum, 6.

40 Jan XXIII, Veterum Sapientia, ,Acta Apostolicae Sedis”, t. 54 (1962), 129-135. 
At the same time, John XXIII defended the Latin language in the life of the Church by issuing the Apostolic Constitution Veterum sapientia (22 February 1962) ${ }^{40}$.

\section{REFORM OF PAUL VI}

The 1962 edition of the Roman Missal was the last model edition of the so-called Trento Missal, which is now used by a number of different Catholic traditionalist communities.

The Second Vatican Council (1962-1965) announced, as the first of its documents, the Constitution on the Sacrosanctum Concilium liturgy $(1963)^{41}$, which is an announcement of a comprehensive reform of the Church's ceremonies and the further changes of the 1950s and $1960 \mathrm{~s}^{42}$.

Some reforms took place during the Council and shortly afterwards (in 1965 and 1967). In 1964, Pope Paul VI allowed Cardinal James Cardinal Lercaro to celebrate the first concelebrated mass with other priests in Bologna (May), and then he himself celebrated such a liturgy at the opening of the Third Council session in the Vatican (September).

In 1965, the custom of common Pater noster recitation by the priest and the faithful in the national languages was introduced, the last Gospel and the prayers of Leo XIII after Mass were omitted, while the common prayer, that is, the prayer of the faithful and the possibility of celebration versus populo were added. Mass readings were introduced in the national languages, as were the songs of Kyrie, Gloria, Credo, Sanctus and Agnus Dei (Inter Oecumenici Instruction) ${ }^{43}$.

${ }^{40}$ John XXIII, Veterum Sapientia, „Acta Apostolicae Sedis”, vol. 54 (1962), 129-135.

${ }^{41}$ Cf. Concilium Vaticanum II, Constitutio de sacra liturgia Sacrosanctum Concilium, in: „Acta Apostolicae Sedis” 56(1964), 97-138.

${ }^{42}$ Cf. S. Czerwik, Odnowa liturgii w świetle konstytucji i instrukcji liturgicznej, „Ruch Biblijny i Liturgiczny” 18(1965)3, 162-174.

${ }^{43}$ Cf. Sacra Rituum Congregatio, Instructio Inter Oecumenici, in: „Acta Apostolicae Sedis", vol. 56 (1964), 877-900. 
$(1963)^{41}$, która stanowi zapowiedź całościowej reformy obrzędów Kościoła i dalszy ciąg zmian z lat 50-tych i 60-tych ${ }^{42}$.

Niektóre reformy miały miejsce już podczas Soboru i krótko po jego zakończeniu $(1965,1967)$. W 1964 r. papież Paweł VI zezwolił, aby Jakub kard. Lercaro odprawił w Bolonii (maj) pierwszą mszę koncelebrowaną wraz z innymi kapłanami, a następnie sam sprawował taką liturgię na otwarcie III sesji soborowej w Watykanie (wrzesień).

W 1965 r. zaprowadzono zwyczaj wspólnego odmawiania Pater noster przez kapłana i wiernych w językach narodowych, pominięto ostatnią Ewangelię i modlitwy Leona XIII po mszy, dodano natomiast modlitwę powszechną czyli modlitwę wiernych oraz możliwość celebracji versus populo. Czytania mszalne zostały wprowadzone w językach narodowych, podobnie jak śpiew Kyrie, Gloria, Credo, Sanctus i Agnus Dei (Instrukcja Inter Oecumenici) ${ }^{43}$.

W dniu 7 marca 1965 r. Paweł VI odprawił w rzymskim kościele pw. Wszystkich Świętych liturgię mszy w języku włoskim (za wyjątkiem Kanonu) przy ołtarzu zwróconym w stronę wiernych.

Posoborowa komisja (Consilium ad exsequendam Constitutionem de Sacra Liturgia $)^{44}$ pracująca nad soborową reformą liturgiczną przygotowała Nowy Porządek Mszy (Novus Ordo Missae), który został ogłoszony przez Pawła VI (1963-1978) w 1969 r. konstytucją apostolską Missale Romanum45. Różne idee ruchu liturgicznego znalazty swój wyraz w tej reformie: czynne uczestnictwo wiernych w obrzędach mszalnych, możliwość sprawowania liturgii versus populo (użycie stołu), koncelebra, szersze wprowadzenie języków

${ }^{41}$ Cf. Concilium Vaticanum II, Constitutio de sacra liturgia Sacrosanctum Concilium, w: „Acta Apostolicae Sedis” 56(1964), 97-138.

${ }^{42}$ Cf. S. Czerwik, Odnowa liturgii w świetle konstytucji i instrukcji liturgicznej, „Ruch Biblijny i Liturgiczny” 18(1965)3, 162-174.

${ }^{43}$ Cf. Sacra Rituum Congregatio, Instructio Inter Oecumenici, w: „Acta Apostolicae Sedis", t. 56 (1964), 877-900.

${ }^{44}$ Cf. J. Stefański, Rola consilium w posoborowej reformie liturgicznej, „Studia Theologica Varsaviensia" 23(1985) 2, 291-310.

45 Paweł VI, Constitutio apostolica Missale Romanum, w: „Acta Apostolicae Sedis", t. 61 (1969), 217-226. 
On March 7, 1965, Paul VI celebrated a Mass in Italian (except the Canon) at the altar facing the faithful in the Roman Church of All Saints.

The post-conciliar committee (Consilium ad exsequendam Constitutionem de Sacra Liturgia ${ }^{44}$ working on the conciliar liturgical reform prepared the New Order of the Mass (Novus Ordo Missae), which was proclaimed by Paul VI (1963-1978) in 1969 with the Apostolic Constitution of Missale Romanum ${ }^{45}$. Various ideas of the liturgical movement found their expression in this reform: active participation of the faithful in mass rituals, the possibility of celebrating the liturgy versus populo (use of the table), concelebration, wider introduction of national languages to the liturgy, reform of the Roman calendar, further reform of Holy Week, elimination of prayers at the steps of the altar, the last Gospel, change of the Offertory, addition of the second reading (and a new division of readings in a three-year cycle into Sundays and two-year cycles into weekdays), introduction of the prayer of the faithful, loud recitation of the Canon, abolition of numerous bows, kneels, kisses of the altar, signs of the cross, and other rubrics.

In 1968-70, the papal ceremonies were also simplified. The reforms also resulted in the shortening of the Breviary (henceforth the Liturgy of the Hours), e.g. in lauds and in vespers (the so-called main hours) the number of psalms was reduced from five to three. After the last reform (the new breviary was announced on November 1, 1970); the entire psalter (three psalms were omitted) is read through within four weeks.

The Roman calendar in the classic era counted more than 230 feast days in the church year. Paul VI shortened that list considerably, leaving 23 feast days and 63 obligatory memories (and 93 free memories). Saints whose biographies were considered historically uncertain, repetitions of the same figures on different days, and 'saints without truly universal significance' were removed from the universal

${ }^{44}$ Cf. J. Stefański, Rola consilium w posoborowej reformie liturgicznej, „Studia Theologica Varsaviensia" 23(1985) 2, 291-310.

${ }^{45}$ Paul VI, Constitutio apostolica Missale Romanum, in: „Acta Apostolicae Sedis", vol. 61 (1969), 217-226. 
narodowych do liturgii, reforma kalendarza rzymskiego, dalsza reforma Wielkiego Tygodnia, likwidacja modlitw u stopni ołtarza, ostatniej Ewangelii, zmiana Offertorium, dodanie drugiego czytania (i nowy podział czytań w cyklu trzyletnim na niedziele, dwuletnim zaś na dni powszednie), wprowadzenie modlitwy wiernych, głośne odmawianie Kanonu, zniesienie licznych pokłonów, przyklęknięć, ucałowań ołtarza, znaków krzyża i innych rubryk.

W 1. 1968-70 zostały uproszczone również ceremonie papieskie. Efektem reform jest także skrócenie Brewiarza (odtąd Liturgii Godzin), np. w jutrzni i w nieszporach (tzw. godziny główne) zmniejszono liczbę psalmów z pięciu do trzech. Po ostatniej reformie (nowy brewiarz został ogłoszony 1 listopada 1970 r.) cały psałterz (pominięto trzy psalmy) odmawiany jest w ciągu czterech tygodni.

Kalendarz rzymski w epoce klasycznej liczył ponad 230 świąt świętych w roku kościelnym. Paweł VI dokonał znacznego skrócenia tej listy, pozostawiając 23 święta i 63 wspomnienia obowiązkowe (oraz 93 wspomnienia dowolne). $\mathrm{Z}$ kalendarza powszechnego ( $\mathrm{Ca}$ lendarium Romanum, 1969 ${ }^{46}$ ) usunięto świętych, których biografie zostały uznane za niepewne historycznie, powtórzenia tych samych postaci w różne dni, oraz ,świętych nie posiadających znaczenia prawdziwie powszechnego". W wyniku tych decyzji zostały m.in. zlikwidowane święta papieży: św. Telesfora (5 stycznia), św. Marcelego (16 stycznia), św. Kleta (26 kwietnia), św. Urbana I (25 maja), św. Stefana (3 lipca) oraz św. Linusa (23 września). Ponadto usunięto np. święto św. Doroty (6 lutego), św. Małgorzaty (20 lipca) i św. Katarzyny Aleksandryjskiej (25 listopada) ${ }^{47}$. Celem Pawła VI było przywrócenie głównego znaczenia niedzieli i celebrowania przede wszystkim świąt związanych ze Zbawicielem (pierwszeństwo tzw.

${ }^{46}$ Calendarium Romanum ex decreto Sacrosancti Oecumenici Concilii Vaticani II instauratum, auctoritate Pauli PP. VI promulgatum, editio typica, Watykan 1969, stron 179.

${ }^{47}$ Cf. K. Konecki, Rok liturgiczny i Kalendarz w reformie Soboru Watykańskiego II, Toruń 2010, 247-284. 
calendar (Calendar Romanum, 1969 ${ }^{46}$ ). As a result of those decisions, the feasts of the following popes were eliminated: St. Telesphore (5 January), St. Marcellus (16 January), St. Anacletus (26 April), St. Urban I (25 May), St. Stephan (3 July) and St. Linus (23 September). In addition, the feasts of St Dorothy (6th February), St Margaret (20th July) and St Catherine of Alexandria (25th November) ${ }^{47}$ were removed. Paul VI's aim was to restore the main meaning of Sunday and to celebrate, above all, feast days related to the Saviour (priority of the so-called temporal over the so-called sanctoral) ${ }^{48}$. The feast of Christ the King was moved from the last Sunday of October to the last, i.e. the thirty-fourth Sunday of the church year at the end of November $^{49}$. In the new church year also dry days and pre-Lenten Season were abolished. From then on, liturgical days are divided into celebrations (solemnitates), i.e. $1^{\text {st }}$ class holidays, holidays (festa), i.e. more precisely $2^{\text {nd }}$ class holidays and memoriae, i.e. $3^{\text {rd }}$ class feast days. Other days have the status of weekdays (feriae).

\section{CONCLUSIONS}

In the literature on liturgical reform, a lot of space is devoted to reflection on Paul VI's decisions. However, in order to learn more about the 1969 reform, it is also necessary to outline the earlier events that led to it. The changes in the liturgy lasted for several decades and their principles explain various aspects of the Council and post-conciliar reform. However, the events of 1955-1962 are less known and for this reason it is worthwhile analyzing them. The reforms of the 20th century were quantitative and qualitative.

${ }^{46}$ Calendarium Romanum ex decreto Sacrosancti Oecumenici Concilii Vaticani II instauratum, auctoritate Pauli PP. VI promulgatum, editio typica, Vatican City 1969, pp. 179.

${ }^{47}$ Cf. K. Konecki, Rok liturgiczny i Kalendarz w reformie Soboru Watykańskiego II, Toruń 2010, 247-284.

${ }_{48}$ Cf. M. Kunzler, Liturgia Kościoła, trans. L. Balter, Poznań 1999, 281.

${ }^{49}$ Cf. J. Superson, Historia uroczystości Jezusa Chrystusa Króla Wszechświata, Kraków 2005. 
temporału nad tzw. sanktorałem) ${ }^{48}$. Święto Chrystusa Króla zostało przeniesione $\mathrm{z}$ ostatniej niedzieli października na ostatnią, 34 niedzielę roku kościelnego pod koniec listopada ${ }^{49}$. W nowym roku kościelnym zniesiono też suche dni i przedpoście. Dni liturgiczne dzielą się odtąd na uroczystości (solemnitates) czyli święta I klasy, święta (festa), czyli ściślej święta II klasy oraz wspomnienia (memoriae), czyli święta III klasy. Pozostałe dni mają rangę dni powszednich (feriae).

\section{WNIOSKI}

W literaturze poświęconej reformie liturgicznej dużo miejsca zajmuje refleksja nad decyzjami Pawła VI. Aby lepiej poznać reformę z 1969 r. niezbędne jest jednak zarysowanie także wcześniejszych wydarzeń, które do niej prowadziły. Zmiany w liturgii trwały przez kilka dziesięcioleci, a ich zasady wyjaśniają różne aspekty reformy soborowej i posoborowej. Wydarzenia w lat 1955-1962 są jednak mniej znane i z tego powodu warto poddawać je analizie. Reformy w XX wieku miały charakter ilościowy i jakościowy. Zmieniły znacząco ryt rzymski. Są stosowane w Kościele powszechnym z dalszymi zmianami, wynikającymi z decyzji ogólnych Kurii Rzymskiej i z przepisów lokalnych (decyzje episkopatów krajowych).

W katolickich środowiskach tradycjonalistycznyc ${ }^{50}$ zmiany liturgiczne są poddawane różnorodnej krytyce, chociaż granica dla akceptowanych zmian (np. rubryk z 1911, 1956, 1962, 1965 i 1969) bywa różnie sytuowana. W r. 2007 papież Benedykt XVI (20052013) pozwolił wspólnotom przywiązanym do klasycznej formy rytu rzymskiego (np. Bractwo Kapłańskie św. Piotra), ale także innym

48 Reforma Pawła VI została nazwana nawet ,końcem średniowiecza” wskutek zmiany tradycyjnych form liturgii rzymskiej. Cf. M. Kunzler, Liturgia Kościoła, przeł. L. Balter, Poznań 1999, 281.

49 Cf. J. Superson, Historia uroczystości Jezusa Chrystusa Króla Wszechświata, Kraków 2005.

50 Cf. M. Karas, Integryzm Bractwa Kapłańskiego św. Piusa X. Historia i doktryna rzymskokatolickiego ruchu tradycjonalistycznego, Kraków 2008. 
They changed the Roman rite significantly. They are applied in the universal Church with further changes, resulting from the general decisions of the Roman Curia and from local regulations (decisions of national episcopates).

In Catholic traditionalist circles ${ }^{50}$, liturgical changes are subject to various criticisms, although the boundary for the approved amendments (e.g. the 1911, 1956, 1962, 1965 and 1969 rubrics) can vary. In 2007, Pope Benedict XVI (2005-2013) allowed communities adhering to the classical form of the Roman rite (e.g. St. Peter's Priestly Brotherhood), but also other clergymen of the Latin rite, to freely use the liturgical books announced by John XXIII in 1962. Thus, an extraordinary form of the Roman rite (motu proprio Summorum Pontificum $)^{51}$ was created. Classical rituals thus gained a new chapter in their centuries-long history.

\section{Summary \\ The Reform of the liturgy during the pontificates of Pius XII and John XXIII}

The paper discusses the principles and the course of the reform of the liturgy of the Missal and Breviary in the Roman Church in the 20th century, in particular for the pontificates of Pius XII and John XXIII. These reforms were discussed against the background of the classic era (of the 19th century and earlier) and in comparison with the reforms of the Second Vatican Council and of Paul VI. The rituals of that era were simplified, renewed in a community spirit and adapted to the mentality of contemporary man and to the new way of life, to the conditions of industrial society. "Acta Apostolicae Sedis".

Key words: Pius XII, John XXIII, reform of the catholic liturgy, Roman missal, Roman breviary \#end ENG

${ }^{50}$ Cf. M. Karas, Integryzm Bractwa Kapłańskiego św. Piusa X. Historia i doktryna rzymskokatolickiego ruchu tradycjonalistycznego, Kraków 2008.

${ }^{51}$ Benedict XVI, Summorum Pontificum, in: „Acta Apostolicae Sedis”, vol. 99 (2007), 777-781. 
duchownym obrządku łacińskiego, na swobodne korzystanie z ksiąg liturgicznych ogłoszonych przez Jana XXIII w 1962 r. Powstała w ten sposób nadzwyczajna forma rytu rzymskiego (motu proprio Summorum Pontificum) $)^{51}$. Obrzędy klasyczne zyskały tym samym nowy rozdział w swej wielowiekowej historii.

\section{Streszczenie \\ Reforma liturgiczna Piusa XII i Jana XXIII}

Artykuł omawia zasady i przebieg reformy liturgii Mszału i Brewiarza w Kościele rzymskim w XX wieku, a zwłaszcza za pontyfikatów Piusa XII i Jana XXIII. Reformy te omówiono na tle epoki klasycznej (XIX w. i wcześniej) oraz w porównaniu do reform II Soboru Watykańskiego i Pawła VI. Obrzędy w tej epoce zostały uproszczone, odnowione w duchu wspólnotowym i dostosowane do mentalności współczesnego człowieka i do nowego sposobu życia, do warunków społeczeństwa przemysłowego. „Acta Apostolicae Sedis”.

Słowa kluczowe: Pius XII, Jan XXIII, reforma liturgiczna, rubryki, Mszał rzymski, Brewiarz

\section{Informacja o autorze}

Prof. dr hab. Marcin Karas (ur. w 1971 r.) jest pracownikiem Zakładu Filozofii Polskiej w Instytucie Filozofii UJ. W swoich badaniach zajmuje się historią filozofii średniowiecznej (kosmologia), poglądami Mikołaja Kopernika, historią idei w dziejach Kościoła katolickiego w XIX i XX w. oraz historiozofią chrześcijańską (myśl Teilharda de Chardin). Opublikował około 10 książek i kilkadziesiąt artykułów. Wydał także przekłady różnych pism filozoficznych.

\section{Bibliografia}

Accattoli L., Kiedy papież prosi o przebaczenie. Wszystkie «mea culpa» Jana Pawła II, przeł. A. Dudzińska-Facca, Kraków 1999.

${ }^{51}$ Benedykt XVI, Summorum Pontificum, w: „Acta Apostolicae Sedis”, t. 99 (2007), 777-781. 
Banaszak M., Historia Kościoła katolickiego, t. 4, Warszawa 1992

Benedykt XVI, Summorum Pontificum, w: „Acta Apostolicae Sedis”, t. 99 (2007), 777-781.

Bugnini A., La riforma liturgica 1948-1975, Rzym 1983

Concilium Vaticanum II, Constitutio de sacra liturgia Sacrosanctum Concilium, w: „Acta Apostolicae Sedis” 56(1964), 97-138.

Czerwik S., Odnowa liturgii w świetle konstytucji i instrukcji liturgicznej, „Ruch Biblijny i Liturgiczny" 18(1965)3, 162-174.

Falise J., Liturgiae practicae compendium sive Sacrorum rituum rubricarumque Missalis Breviarii et Ritualis Romani compendiosa elucidatio, ed. 2, Ratyzbona 1876.

Karas M., Integryzm Bractwa Kapłańskiego św. Piusa X. Historia i doktryna rzymskokatolickiego ruchu tradycjonalistycznego, Kraków 2008.

Karas M., Z dziejów Kościoła. Ciagłość i zmiana w Kościele rzymskokatolickim w XIX i XX wieku, Sandomierz 2008

Konecki K., Rok liturgiczny i Kalendarz w reformie Soboru Watykańskiego II, Toruń 2010, 247-284.

Krzystek A., Przedsoborowe «drogi» do generalnej reformy liturgicznej Soboru Watykańskiego II, „Colloquia Theologica Ottoniana” (2005)1, 7-24.

Kunzler M., Liturgia Kościoła, przeł. L. Balter, Poznań 1999, 281.

Małaczyński F., Ceremoniał obrzędów Wielkiego Tygodnia, Warszawa 1958.

Nowowiejski A., Ceremoniat parafialny. Przewodnik liturgiczny dla duchowieństwa pasterstwem dusz zajętego, wyd. 7, Płock 1931, stron 574.

Nowowiejski A., Msza Święta, Warszawa 2001.

Paweł VI, Constitutio apostolica Missale Romanum, w: „Acta Apostolicae Sedis”, t. 61 (1969), 217-226.

Pius XII, Christus Dominus, w: „Acta Apostolicae Sedis” t. 45 (1953), 15-24.

Pius XII, In cotidianis precibus, w: „Acta Apostolicae Sedis”, t. 37 (1945), 65-67.

Pius XII, Mediator Dei, w: „Acta Apostolicae Sedis”, t. 39 (1947), 521-600, a także Pius XII, Mediator Dei, Kielce 1947.

Pius XII, Sacram communionem, w: „Acta Apostolicae Sedis” t. 49 (1957), 177-178.

Pylak B., Msza św. ofiara społeczna, w: B. Pylak, W stużbie Bożej prawdy, Lublin 1986, 141-155.

Ratzinger J., Wprowadzenie w chrześcijaństwo, przeł. Z. Włodkowa, wyd. 2, Kraków 1994.

Sacra Rituum Congregatio, Instructio Inter Oecumenici, w: „Acta Apostolicae Sedis", t. 56 (1964), 877-900. 
Stefański J., Abp A. Bugnini (1912-1982), promotor posoborowej odnowy liturgicznej, ,Ruch Biblijny i Liturgiczny”, 36(1983)4, 329-334.

Stefański J., Rola consilium w posoborowej reformie liturgicznej, „Studia Theologica Varsaviensia" 23(1985) 2, 291-310.

Superson J., Historia uroczystości Jezusa Chrystusa Króla Wszechświata, Kraków 2005.

Wójcik S., Wielki Tydzień wedlug porządku wznowionego, Warszawa 1957.

Zegza M., Historia i problemy postu eucharystycznego, „Ruch Biblijny i Liturgiczny", 8(1955)1, 47-57.

Zieliński Z., Papiestwo i papieże dwóch ostatnich wieków, Warszawa 1983.Stefański J., Abp A. Bugnini (1912-1982), promotor posoborowej odnowy liturgicznej, „Ruch Biblijny i Liturgiczny”, 36(1983)4, 329-334.

Stefański J., Rola consilium w posoborowej reformie liturgicznej, „Studia Theologica Varsaviensia" 23(1985) 2, 291-310.

Superson J., Historia uroczystości Jezusa Chrystusa Króla Wszechświata, Kraków 2005.

Wójcik S., Wielki Tydzień wedtug porządku wznowionego, Warszawa 1957.

Zegza M., Historia i problemy postu eucharystycznego, „Ruch Biblijny i Liturgiczny", 8(1955)1, 47-57.

Zieliński Z., Papiestwo i papieże dwóch ostatnich wieków, Warszawa 1983. 
